\title{
Mengelola Potensi Destruktif Olahraga Ke Arah Pengembangan Kebijakan Olahraga Yang Komprehensif
}

\author{
Syarifudin \\ Fakultas Ilmu Keolahragaan Universitas Negeri Jakarta \\ Abdi Rahmat \\ Jurusan Sosiologi Universitas Negeri Jakarta
}

\begin{abstract}
Abstrak: Olahraga umumnya mencerminkan nilai-nilai apa yang menjadi rujukan masyarakat. Olahraga dapat menjadi wahana untuk membina dan sekaligus membentuk watak kepribadian. Di sisi lain, olahraga dapat pula menyebarkan nilai-nilai pertentangan atau konflik dan bahkan bisa mempersubur masalah sosial seperti: diskriminasi, ketidakjujuran, korupsi dan praktek suap, pemukulan wasit, perkelahian antarpemain atau antarsupporter, bahkan antarkeduanya, serta berbagai bentuk konflik lainnya. Karena itu, tulisan ini bertujuan untuk menguraikan akar permasalahan perilaku potensi destruktif olahraga tersebut yang dapat mengancam integrasi sosial bahkan integrasi bangsa. Tulisan ini juga mengajukan tawaran suatu pola pengembangan olahraga yang dapat meminimalisir potensi destruktif tersebut melalui suatu kebijakan keolahragaan yang komprehensif.
\end{abstract}

Kata Kunci: olahraga, perilaku destruktif, integrasi sosial, pembinaan olahraga

\begin{abstract}
Sport reflects positive values referred by society. Sport can be a medium for building people character and personality. In the other hand, sport can also be an arena in spreading tensions and conflicts among groups of people, even fostering other social problems, like discrimination, unfairness, corruption and bribery, violence among players or supporters, and etc. Therefore, this article aims at describing the root of problem of destructive dimensions of sport that can threaten social integration, even national integration. This article offers some formulas of sport development that can minimize destructive potencies of the sport through a comprehensive sport policy.
\end{abstract}

Key words: sport, destructive behavior, social integration, sport coaching

\section{Pendahuluan}

Bagi masyarakat yang maju dan modern kegiatan olahraga sudah menjadi kebutuhan dalam kehidupan sehari-hari. Olahraga telah dipandang memiliki berbagai fungsi yang tidak hanya untuk mengembangkan kualitas kebugaran fisik saja, melainkan juga mengembangkan kualitas mental individu dan masyarakat secara lebih utuh dan mantap. Melalui olahraga, individu dapat mengembangkan segi-segi mental kepribadian, moral, kepemimpinan, kesetiaan, loyalitas, pengabdian, relasi intra dan interpersonal lebih baik lagi. Karena itu, tidak berlebihan jika dikatakan bahwa, olahraga memberikan pembelajaran dalam membangun budaya keunggulan dalam arti yang luas.

Para ahli menyatakan (Ateng, 1992:24) bahwa olahraga pada umumnya mencerminkan nilai-nilai yang menjadi rujukan masyarakat. Selain itu, olahraga juga merupakan suatu arena hiburan yang menyuguhkan keterampilan, dan pada saat bersamaan seseorang dapat belajar tentang nilai inti kebudayaannya. Berdasarkan asumsi tersebut, diyakini bahwa olahraga itu dapat menjadi wahana untuk membina dan sekaligus membentuk watak kepribadian. Akan tetapi, di samping membawa potensi-potensi kebaikan seperti itu, olahraga seringkali mengandung potensi-potensi untuk menyebarkan nilai-nilai pertentangan atau konflik dan bahkan bisa mempersubur masalah sosial seperti: diskriminasi, ketidakjujuran, korupsi dan praktek suap, kekerasan serta berbagai bentuk konflik lainnya.

Nilai diskriminasi terlihat misalnya masih munculnya rasialisme yang dilakukan oleh suatu komunitas olahraga terhadap misalnya atlet berkulit hitam. Dalam kasus sepakbola internasional, persoalan rasialisme ini telah menjadi 
komitmen FIFA sebagai induk sepakbola dunia untuk memerangi dan memberantas. Begitu pula di cabang-cabang olahraga lainnya. (www.kapanlagi.com)

Adapun nilai ketidakjujuran tampak dalam kasus-kasus doping oleh para atlet demi mendapatkan prestasi tertinggi melalui jalan pintas yang tidak jujur. Atau kasus diving di arena sepakbola yang mencerminkan ketidakjujuran dan juga memancing emosi penonton. Begitu pula, praktek ketidakjujuran yang dilakukan oleh sebagian kalangan pengurus olahraga baik di tingkat klub-klub olahraga maupun di tingkat organisasi olahraga. Misalnya, kasus pengaturan skor pertandingan yang banyak terjadi di berbagai kompetisi olahraga. Yang cukup menghebohkan adalah kasus pengaturan penunjukkan wasit di kompetisi seri A Italia beberapa tahun yang lalu yang terkenal dengan kasus Moggiopoli. Atau kasus dugaan menerima suap yang dituduhkan oleh salah satu peserta kompetisi sepakbola nasional terhadap salah seorang pengurus di Komisi Disiplin PSSI. (bolanews.com/lilianto_apriadi/15447.php)

Sementara itu, contoh nilai kekerasan adalah kasus-kasus pemukulan wasit, perkelahian antar pemain atau antar supporter, bahkan antar keduanya. Kasus-kasus ini sering terjadi di kompetisi sepakbola tanah air baik di tingkat antar kampung bahkan sampai di tingkat kompetisi yang paling elit yaitu Liga Super Indonesia (Amiq, 2008).

Karena kegiatan olahraga melibatkan banyak orang yang saling berinteraksi atau berkomunikasi satu sama lain, maka tidak mengherankan jika terdapat pula banyak kepentingan di dalamnya. Pada satu sisi, olahraga menjadi arena yang memadukan dan mengintegrasikan semua kepentingan, kebutuhan, dan harapan setiap orang yang terlibat, dalam arti berfungsi memfasilitasi ekspresi setiap individu atau kelompok. Pada sisi lain, olahraga sekaligus berpotensi menjadi sumber pertentangan berbagai orang yang terlibat di dalamnya. Dari segi ini, olahraga bukan hanya dapat memberikan sumbangan positif bagi kehidupan, tetapi juga mengandung potensi negatif yang harus dicegah.

Pada tataran tertentu, kenyataan itu dapat menjadi gangguan atas ketenteraman masya- rakat, dan bahkan dalam skala yang luas berpotensi mengancam persatuan nasional. Meskipun bidang olahraga, secara umum kerap dipandang netral atau sekurang-kurangnya agak relatif steril dari kepentingan politik, namun tidak dapat disangkal bidang tersebut tetap menjadi bagian yang tidak terpisahkan dari identitas simbolik bangsa secara keseluruhan. Dalam konteks kehidupan kebangsaan, secara paradoks, olahraga dapat menjadi sumber kekuatan penyatu, sekaligus pemecah, yang bersumber dari benih-benih perilaku destruktif yang perlu diwaspadai. Untuk itu, tulisan ini berusaha menjelaskan apa saja bentuk-bentuk perilaku destruktif itu serta bagaimana sepatutnya kita mewaspadainya. Selanjutnya, akan diajukan langkah-langkah dan jalan keluar yang perlu ditempuh untuk menanggulanginya

\section{Kajian Literatur dan Pembahasan}

\section{Akar-Akar Permasalahan}

Salah satu persoalan penting yang perlu mendapat perhatian dalam pengelolaan olahraga dewasa ini adalah masih seringnya terjadi berbagai insiden-insiden berupa tindakantindakan destruktif yang muncul dalam berbagai musim kompetisi atau pertandingan. Bahkan dapat dikatakan dalam setiap musim atau kompetisi pertandingan, khususnya di tingkat nasional kita melihat, nyaris tidak pernah sepi dari adanya insiden-insiden yang merusak. Hal itu seperti tawuran, perkelahian, pemukulan, perusakan fasilitas, dan lain-lain. Kejadiankejadian tersebut hakikatnya telah berlangsung sejak lama (Amiq, 2008:34).

Hanya saja, dewasa ini insiden-insiden itu kerap kali muncul dalam intensitas yang lebih tinggi dan menyebar pada berbagai kota di sejumlah daerah. Jadi, amuk penonton bukan lagi terjadi di Jakarta saja. Umumnya insiden-insiden tersebut terjadi dalam jenis-jenis olahraga berkelompok yang melibatkan massa dalam jumlah besar, seperti sepakbola. Meskipun, bidang di luar sepakbola bukannya bersih atau steril dari tindakan-tindakan destruktif itu, namun bidang sepakbola, membuka peluang yang lebih besar bagi adanya tindakan detruktif tersebut. Gejala ini memang sebagaimana yang dikonseptualisasi secara sosiologis oleh Blumer sebagai gejala 
kerumunan ekspresif (expressive crowd) yang mempunyai emosi dan logika tersendiri yang bisa melahirkan tindakan kolektif yang tidak rasional (Ritzer, 2005:60).

Akan tetapi, jika dicermati secara mendalam dan obyektif, sesungguhnya perilaku destruktif dalam olahraga itu bukan saja insiden-insiden perusakan yang berbentuk fisikal saja tetapi juga pada dimensi yang lebih luas, seperti yang telah diuraikan sebelumnya, mencakup: penggunaan doping pemain, korupsi pengurus atau birokrat olahraga, penyuapan terhadap wasit, hakim, pemain dan sejenisnya. Tindakan tersebut, secara keseluruhan merupakan bagian dari perilaku destruktif yang memberikan implikasi luas terhadap kelangsungan kegiatan olahraga dan bahkan keutuhan bangsa. Dalam bentuknya yang kongkrit, tindakan semacam itu, akan menggerogoti mentalitas dan secara otomatis melemahkan ketahanan bangsa. Bagaimana perkembangan olahraga dapat maju, jika pendekatan yang ditempuh memberi ruang yang leluasa bagi tumbuhnya korupsi dan penyalahgunaan wewenang?

Adapun sebab-sebab timbulnya tindakan destruktif itu biasanya bermacam-macam, dengan maksud yang berbeda-beda pula. Mulai dari yang bermotif spontan, sampai dengan yang bertendensi politik (Kartono, 1994:32). Karena itu, penanganannya harus bersifat komprehensif pula. Namun yang jelas, tindakan tersebut, sebagian besar nyaris dilakukan penonton, yang biasanya tidak puas terhadap hasil-hasil pertandingan maupun keputusan tertentu yang dijatuhkan wasit. Rasa kekesalan yang ditumpahkan secara spontan ini terkadang tidak terkendali, dan dalam ukuran tertentu menjadikan mereka beringas menghancurkan apa saja yang dihadapi.

Salah salah satu sedikit contoh yang bertahun-tahun sukar dilenyapkan, dan membuat repot sejumlah pihak adalah ulah para supporter Persebaya dari Surabaya, yang lebih dikenal dengan "bonek" (bondo nekad/bermodal kenekatan), yang datang ke setiap kota-kota tempat tim kesayangannya bertanding, seraya membuat kekisruhan di sana. Tindakan mereka yang mempertontonkan kekasaran dan cenderung mengabaikan aturan sering menjadi beban tahunan pihak-pihak penyelenggara pertandingan maupun masyarakat di sekitarnya. Pihak keamanan sendiri seolah enggan bertindak tegas, sehingga seolah tidak berdaya menghadapi mereka. Contohnya adalah bagaimana final sepakbola Liga Indonesia tahun 2008 antara tim PSMS Medan dan Sriwijaya FC terpaksa dilakukan di Bandung dalam suasana tertutup, demi untuk menghindari konflik antar supporter.

Munculnya perilaku destruktif tersebut sesunguhnya tidaklah berdiri sendiri, namun terkait dengan berbagai problem yang lebih kompleks, baik yang bersumber dari penonton, pemain, wasit, pengurus dan bahkan juga masyarakat luas. Penonton yang tidak disiplin dan kurang terdidik biasanya tingkat kesadarannya rendah dan mudah tersulut emosinya. Sedangkan pemain yang tidak menunjukkan mutu permainan yang bagus, tidak bermain secara fair dapat pula menjadi sumber konflik. Di samping itu, sikap dan keputusan para wasit serta hakim yang dinilai tidak adil dan obyektif berpotensi besar menyulut tindakan-tindakan destruktif itu (Houlihan, 1997: 56).

Namun di luar itu, yang jauh lebih penting, sumber dari tindakan-tindakan yang tidak terpuji tersebut adalah kondisi masyarakat secara keseluruhan. Pada kenyataannya seperti ditegaskan oleh Ateng (1992:30) dunia olahraga menjadi cermin mikro atas situasi makro di sekelilingnya. Di tengah-tengah kehidupan bangsa yang carut-marut dewasa ini, mudah bagi siapapun untuk melakukan tindakan-tindakan di luar akal sehat mereka. Kondisi kehidupan ekonomi yang semakin sulit, kebutuhan pokok yang terus merangkak naik, biaya pendidikan dan kesehatan yang semakin tidak terjangkau, menjadikan orang mudah frustrasi dan untuk sebagiannya menemukan salurannya pada aktifitas-aktifitas sosial yang melibatkan orang banyak, yang mana salah satunya adalah olahraga.

\section{Kaitan Antara Perilaku Destruktif Dunia Olahraga Dengan Integrasi Sosial}

Seperti dikemukakan di atas, bahwa bidang olahraga pada hakikatnya bukanlah persoalan yang berdiri sendiri, terpisah dari faktor-faktor lain, yang hakikatnya secara tidak langsung mencerminkan realitas di tengah-tengah masyarakat 
dan menjadi bagian integral dari kehidupan bangsa secara keseluruhan, maka apapun yang terjadi dalam bidang olahraga, sedikit banyak pasti akan memberikan pengaruh kepada masyarakat.

Demikian pula, munculnya fenomena destruktif dalam berbagai bentuknya di bidang olahraga, jika terus berlangsung akan memberikan pengaruh kuat terhadap merosotnya keutuhan bangsa. Logikanya adalah dengan timbulnya tawuran dan kekerasan antar supporter, gejala suap, sogokmenyogok, manipulasi dana, taktik "mengatur kemenangan", "sepakbola sabun" dan sejenisnya, sebagaimana telah diterangkan sebelumnya, dipastikan bakal meruntuhkan mentalitas para insan olahraga, yang bagaimanapun akan menghambat usaha-usaha pengembangan bidang olahraga lebih maju lagi. Merosotnya bidang ini pada saatnya akan bertemu terakumulasi dengan bidang-bidang lain, yang secara bersamaan saling melengkapi satu sama lain menumpuk dalam satu bentuk krisis nilai-nilai bangsa. Ini berarti sama artinya dengan mengancam eksistensi bangsa itu sendiri.

Selanjutnya, fenomena destruktif yang muncul dalam bentuk kekerasan fisik seperti: tawuran, perkelahian antar pemain maupun penonton, pada hakikatnya jika dibiarkan secara terus menerus, bukan tidak mungkin, secara kebetulan ataupun sengaja dapat berdampingan dengan munculnya isu-isu lain seperti: ketimpangan, kemiskinan, kesenjangan, etnis, kelompok, maupun agama, yang berpeluang dimanfaatkan pihak-pihak tertentu yang tidak bertanggungjawab (Munir, 2005: 48).

Karenanya, kekhawatiran atas insiden-insiden semacam itu perlu dijadikan landasan agar kita tidak bersikap toleran atas berbagai konflik dan tindak kekerasan yang terus ada dalam dunia olahraga. Apalagi dalam kondisi kehidupan masyarakat yang berat belakangan ini. Bukan tidak mungkin, momen olahraga dijadikan media pelepasan emosi sejumlah individu atau kelompok untuk menumpahkan kekecewaannya atas situasi yang menghimpit, ataupun bahkan sarana mediasi untuk sasaran yang lebih jauh, yakni mengguncang stabilitas nasional dengan memanfaatkan bidang olahraga sebagai entry point.
Begitu pula, adanya perasaan terdiskriminasi oleh kalangan komunitas olahraga di daerah karena kebijakan pembinaan olahraga dari birokrasi olahraga pusat lebih memberi perhatian bahkan previllege kepada kelompok atau daerah tertentu. Hal ini tentu berpotensi memunculkan kecemburuan bagi daerah-daerah lain karena merasakan adanya kesenjangan yang serius dalam pembinaan olahraga. Perasaan terdiskriminasi ini jika tidak secara cermat diatasi akan dapat mengancam integrasi bangsa. Kasus protes pendukung Persipura terhadap PSSI dalam final Copa Indonesia tahun 2009 yang membawabawa isu NKRI adalah contoh luapan perasaan terdiskriminasi tersebut dalam konteks olahraga nasional (Kompas, 3 Agustus 2009; Detiksport. com, 30 Juni 2009).

\section{Pengembangan Kebijakan Olahrahga Yang Komprehensif}

Berdasarkan uraian di atas maka ada beberapa jalan keluar yang perlu ditempuh agar dapat melenyapkan atau minimal mengurangi berbagai tindakan destruktif dalam bidang olahraga.

Pertama, adalah pembinaan olahraga kepada atlet yang lebih maksimal dan merata di seluruh tanah air. Di samping itu perlu juga pengawasan terhadap mereka. Adanya ketimpangan pembinaan olahraga selama ini, antara pusat (Jakarta) dan daerah, atau antara Jawa dan Luar Jawa, selama ini menjadi salah satu sumber persoalan yang ikut menyumbang kepada ketidakberesan bidang keolahragaan, khususnya dalam hal timbulnya perilaku-perilaku destruktif.

Pembinaan yang lebih terfokus di Jakarta maupun Jawa pasti akan membawa efek peningkatan kualitas pada atlet setempat. Karena fasilitas yang lebih memadai dan pembinaan yang berjalan lancar, maka mereka lebih mudah berlatih, kualitas dan kemampuan tekniknya lebih baik, sehingga kesempatan untuk memenangkan kompetisi lebih terbuka. Dalam banyak kesempatan atlet-atlet dari Jakarta maupun Jawa pasti lebih banyak diuntungkan. Sementara di pihak lain, atlet-atlet di daerah-daerah di luar kedua wilayah tersebut, kurang terbina dengan baik, karena biaya dan fasilitas olahraga yang tersedia tidak memadai, sedang pembinaan hanya 
bersifat insidental belaka. Akibatnya keterampilan teknisnya tidak meningkat dan mentalitas atlet tetap rendah.

Keadaan ini secara tidak langsung akan berdampak nyata dalam setiap musim kompetisi olahraga. Terlihat para atlet dari daerah-daerah atau tim-tim yang lemah akan merasakan bahwa mereka tidak dapat mengimbangi secara sepadan kemampuan teknis para pemain dari Jakarta atau Jawa yang hampir selalu mendominasi juara dalam berbagai kompetisi. Pada gilirannya, ketimpangan dalam permainan di lapangan berpotensi besar menimbulkan kekecewaan berbagai pihak, khususnya pihak yang kalah. Di pihak atlet atau pemain, yang merasa bakal kalah, pasti akan terdorong untuk melakukan berbagai taktik dan cara yang tidak baik untuk dapat mengimbangi atau menahan lawan. Mereka misalnya, akan cenderung bermain kasar, manipulasi atau trik-trik tertentu dalam permainan dan sejenisnya.

Tindakan tersebut dalam banyak hal pasti bakal menimbulkan insiden di lapangan dan berpengaruh besar kepada para pendukungnya. Para pendukung pihak yang kalah maupun menang, sebagiannya pasti ada yang tidak dapat menerima realitas itu. Ketidakpuasaan semacam itu dalam banyak kasus mendorong orang untuk bertindak dengan cara-cara yang tidak elegan, bahkan tidak mungkin akan menumpahkan dengan cara-caranya sendiri di "luar lapangan". Berbagai insiden yang muncul dalam olahraga salah satunya adalah karena ketidaksiapan mental, baik dari para pemain maupun penonton dalam menghadapi kenyataan di lapangan (Lutan, 2000: 14).

Karena itu, dalam diri para atlet maupun penonton perlu ditanamkan mentalitas yang sportif, baik menerima kemenangan maupun kekalahan. Dalam kaitan ini sudah selayaknya momentum otonomi daerah sekarang dijadikan salah satu sarana bagi daerah-daerah untuk memajukan pembangunan bidang olahraga lebih serius dalam rangka memajukan bibit-bibit menyalurkan bibit-bibit potensi daerah untuk menjadi atlet yang bermental tangguh.

Kedua, adalah pembinaan terhadap penonton atau supporter. Penonton merupakan aset penting dalam olahraga. Keberadaan mereka turut memberikan sumbangan dalam memajukan bidang olahraga. Dewasa ini, kedudukan olahraga nyaris sama dengan bidang industri perfilman, di mana film tanpa penonton pasti akan mati. Begitu pula olahraga, tanpa penonton pasti akan mundur. Selama ini, kebanyakan orang hanya menyoroti olahraga dari sudut pemain dan pengurusnya saja, namun kurang memberikan perhatian yang memadai kepada aspek penonton ini. Padahal justru banyak sekali persoalan-persoalan dalam bidang olahraga yang timbul karena ulah penonton tersebut. Hal itu berbentuk berbagai perilaku mereka yang menjurus pada tindakantindakan yang merugikan.

Pembinaan terhadap penonton merupakan bagian dari proses pendidikan keolahragaan kepada masyarakat secara tidak langsung. Salah satu caranya adalah, pembentukan fans-fans club di setiap bidang olahraga di daerah-daerah. Organisasinya lebih bersifat longgar, mandiri, dalam bentuk paguyuban yang informal, dengan struktur pengorganisasian yang terbuka. Melalui pembinaan semacam itu diharapkan perilaku massa dapat dikendalikan atau minimal dapat dikontrol. Di samping itu, diharapkan mereka lebih bertanggungjawab dan tidak liar sebagai gerombolan. Adanya fans-fans club ini, akan memudahkan setiap club olahraga untuk menanamkan fanatisme dan loyalitas di antara pendukungnya ke arah yang lebih positif, sekaligus memudahkan sosialisasi atas berbagai permasalahan keolahragaan setempat yang berkaitan. Dari segi ini, pengorganisasian penyokong club, sekaligus dapat menjadi sarana komunikasi yang merekatkan hubungan antara pemain atau atlet dan penyokongnya.

Keberadaan fans-fans club, ternyata cukup membantu usaha dalam mencegah timbulnya efekefek negatif dalam olahraga. Melalui persamaan hobi dan minat ini masyarakat dipersatukan dan memperoleh manfaat, sehingga tidak lagi khawatir bakal timbulnya tindakan-tindakan berbahaya yang berasal dari konflik atau kekerasan penonton selama ini. Pada tingkat nasional, kiranya keberadaan berbagai fans-fans club di atas perlu di "koordinasikan" sedemikian rupa, tanpa harus disatukan dalam bentuk organisasi formal, agar terjadi saling hubungan dan komunikasi yang baik antar kelompok-kelompok penonton dari berbagai daerah. Beberapa fans club yang ada, 
misalnya dalam bidang sepakbola seperti, di Jakarta, Surabaya, Malang, Palembang, Medan, Ujung Pandang, dan lain-lain perlu diperluas lagi di daerah-daerah lain dengan koordinasi yang lebih baik (Amiq, 2008).

Ketiga, adalah pembinaan dan pengawasan terhadap wasit dan hakim di lapangan. Usaha untuk meminimalisir berbagai tindakan destruktif dapat pula dilakukan melalui pembinaan kalangan wasit dan hakim. Berbagai konflik dan kekerasan yang terjadi dalam bidang olahraga selama ini terjadi salah satunya adalah bersumber dari perilaku wasit dan hakim di lapangan yang tidak adil dan tegas (Coackley 2001: 43). Kita menyaksikan bagaimana dalam beberapa peristiwa pertandingan di sejumlah tempat, berbuntut menjadi kekacauan karena keputusan wasit yang keliru, kontroversial, tidak obyektif dan berat sebelah. Bahkan dalam beberapa kasus mereka diduga terlibat kasus suap, sehingga merugikan banyak pihak.

Akibatnya muncul reaksi luas di masyarakat, yang ujung-ujungnya berakhir dengan konflik antar pihak-pihak yang terlibat. Perbuatan wasit yang tercela semacam ini, kerap menjadi sumber konflik yang tidak mudah diselesaikan. Dampak yang ditimbulkannya bukan hanya terbatas dalam lingkaran lapangan pertandingan saja, namun jauh menembus ruang kehidupan masyarakat umum dalam bentuk adanya pertentangan di masyarakat. Karena itu, adanya wasit yang adil, jujur dan berintegritas tinggi, menjadi syarat mutlak untuk menghindari potensi munculnya perilaku-perilaku yang merusak dalam olahraga. Langkah ke arah tersebut hanya dapat terwujud, jika model pembinaan dan pengawasan terhadap wasit dilakukan secara benar.

Keempat, adalah pembinaan dan pengawasan terhadap pelatih, official atau pengurus olahraga, termasuk para birokrat di Kementerian Pemuda dan Olahraga sendiri. Adanya pembinaan dan pengawasan tersebut diharapkan dapat menjadikan pihak-pihak terkait lebih bekerja secara sungguh-sungguh sesuai dengan tuntutan dan target yang ditetapkan. Jangan sampai kebijakan-kebijakan yang dikeluarkan membawa dampak negatif terhadap para pemain. Beberapa pihak yang disebut di atas, memiliki peran yang sangat strategis, mengingat di tangan merekalah sesungguhnya arah kebijakan dan pelaksanan olahraga ditentutkan. Kesalahan dalam pengambilan kebijakan akan berakibat fatal dan bahkan menghancurkan.

Apalagi, jika mereka sampai terlibat dalam berbagai macam tindakan tidak terpuji seperti praktek-praktek korupsi, baik melalui manipulasi dana, penggelembungan alokasi anggaran, sogok-menyogok, sampai dengan "mengatur kemenangan" di lapangan, maka tidak boleh ditolerir. Karena efek yang ditimbulkan atas perbuatan itu sangat besar implikasinya bagi kemajuan olahraga. Sebagai contoh sederhana, bagaimana atlet suatu negara dapat menjuarai event-event kompetisi secara gemilang, kalau standar makanan yang disantap saja tidak memenuhi standar hygienis yang ditetapkan, atau perlengkapan mereka tidak memadai karena sudah "disunat" di sana-sini? Adakah tuntutan menjadi juara itu realistik? Atau bagaimana prestasi olahraga dapat meningkat kalau organisasi pembina keolahragaannya sendiri tidak mampu menyelesaikan tanggunggjawab keuangannya sendiri dengan baik? Dalam kaitan ini, pengawasan dari masyarkat sangat penting, baik itu media massa maupun kelompok-kelompok lain yang peduli dan punya kaitan dengan bidang keolahragaan.

Kelima, penerapan peraturan yang tegas. Melalui penerapan peraturan yang konsisten diharapkan semua pihak akan tunduk dan mematuhinya. Timbulnya berbagai masalah dalam bidang olahraga selama ini terjadi, salah satunya adalah karena kurang adanya penerapan aturan secara tegas, menyangkut beberapa aspek. Berbagai pihak berusaha untuk memanfaatkan celah aturan yang ada untuk mengamankan kepentingannya. Bahkan tidak jarang untuk suatu kepentingan politis individu atau kelompok, integritas bidang olahraga dikorbankan. Peraturan dikesampingkan dan pasal-pasal dalam peraturan dimanipulasi secara sepihak. Sebagai contoh, apa yang terjadi dengan ketua PSSI sekarang ini yang terus ditekan pihak FIFA untuk mundur?

Kita perlu membuang kebiasaan-kebiasaan buruk, sikap tidak konsisten, yang justru akan mencoreng harga diri bangsa. Akibat dari penerapan peraturan yang tidak tegas, adalah 
setiap kali ada insiden kita ragu-ragu menjatuhkan sanksi. Pertimbangan-pertimbangan di luar hukum seringkali lebih mengemuka dibanding kepentingan untuk menegakkan peraturan. Penyalahgunaan peraturan dalam skala apapun merupakan perilaku destruktif, yang jika dibiarkan secara terus menerus, secara sosial pada gilirannya akan menjadi blunder yang merusak ketahanan bangsa (Dault, 2007: 28).

Dalam kaitannya dengan bidang olahraga, penyalahgunaan peraturan dalam bidang ini, cepat atau lambat, besar atau kecil, pada saatnya nanti bersama bidang-bidang lain, secara akumulatif berpotensi menyumbang kepada melemahnya ketahanan bangsa secara menyeluruh. Karena itu, penerapan peraturan yang tegas sejak dini menjadi katup penyelamat, atau benteng awal terhadap potensi-potensi yang merusak. Dari segi ini, penegakan aturan olahraga merupakan suatu keharusan yang tidak dapat ditawar-tawar oleh siapapun.

\section{Simpulan dan Saran}

\section{Simpulan}

Bidang olahraga pada intinya telah menjadi bagian dari kehidupan sehari-hari banyak orang. Di dalamnya terkandung berbagai dimensi penting, yang memberikan manfaat, baik secara fisikal maupun mental. Akan tetapi, di samping itu, olahraga juga memberikan dampak samping berupa potensi konflik, mengingat di dalamnya terkandung beragam kepentingan dan nilai-nilai yang saling bertentangan, yang melibatkan pelaku atau aktor-aktor yang lebih luas, mulai dari pemain, penonton, wasit, pelatih dan pengurus, birokrat bidang olahraga, serta masyarakat luas. Karena itu, dalam skala tertentu, bidang olahraga berpotensi besar membawa dampak berupa munculnya perilaku destruktif yang menganggu kehidupan umum, atau bahkan mengancam persatuan bangsa yang pada ahirnya pemicu terjadi distegrasi bangsa.

Perilaku destruktif dalam olahraga tersebut banyak dilakukan oleh kalangan penonton yang biasanya tidak puas terhadap hasil-hasil pertandingan maupun keputusan tertentu yang dijatuhkan wasit. Rasa kekesalan biasanya ditumpahkan secara spontan ini dan menjadi terkadang tidak terkendali. Namun demikian, perilaku destruktif tersebut sesunguhnya tidaklah berdiri sendiri, namun terkait dengan berbagai problem yang lebih kompleks, baik yang bersumber dari penonton, pemain, wasit, pengurus dan bahkan juga masyarakat luas. Penonton yang tidak disiplin dan kurang terdidik biasanya tingkat kesadarannya rendah dan mudah tersulut emosinya. Sedangkan pemain yang tidak menunjukkan mutu permainan yang bagus, tidak bermain secara fair dapat pula menjadi sumber konflik. Di samping itu, sikap dan keputusan para wasit serta hakim yang dinilai tidak adil dan obyektif berpotensi besar menyulut tindakantindakan destruktif itu. Begitu pula dengan kebijakan-kebijakan dari para birokrat atau pengurus organisasi olahraga yang dianggap tidak adil dan diskriminatif dapat pula menyumbang perilaku destruktif tersebut.

Munculnya tindakan-tindakan destruktif dalam bidang olahraga perlu diwaspadai, karena apapun alasannya bidang olahraga sesungguhnya merupakan dunia mikro yang mencerminkan keadaan di sekelilingnya yang lebih luas. Secara tidak langsung, bidang olahraga dapat menjadi cermin untuk mengukur sejauh mana tingkat kohesifitas masyarakat. Berdasarkan alasan tersebut, kita perlu bersikap proaktif membendung segala potensi dan bentukbentuk perilaku negatif yang merusak di dalamnya.

\section{Saran}

Beberapa cara yang perlu ditempuh untuk mencegah secara dini timbulnya perilaku-perilaku destruktif di atas adalah dengan melakukan usaha-usaha reorientasi pembinaan yang lebih serius dan sistematis dari berbagai aspek, baik itu menyangkut pemain, penonton, wasit, pelatih dan pengurus, birokrat olahraga, dan masyarakat luas. Menurut hemat penulis, langkah ini merupakan kebijakan yang realistik dan perlu secara terus menerus dilakukan. Munculnya berbagai konflik dan kekerasan secara berulangkali dalam bidang olahraga dewasa ini, menunjukkan adanya kegagalan kita dalam melakukan pembinaan yang baik, sekaligus menjadi cermin akan adanya sesuatu ketidakberesan yang meluas dalam masyarakat kita. Karena itu, komunikasi dan koordinasi yang baik di antara para stakeholder olahraga baik itu para 
atlet, perangkat pertandingan, penonton, pengurus klub olahraga, birokrat olahraga baik di tingkat nasional maupun di daerah, begitu juga dengan masyarakat luas, perlu dilakukan secara berkesinambungan agar olahraga dapat terusmenerus menyumbang nilai-nilai positif bagi masyarakat dan pada saat yang sama dapat meminimalisir potensi destruktifnya.

\section{Pustaka Acuan}

Amiq, Fahrial. 2008. Suporter Sepakbola Indonesia. Tesis Program Pascasarjana Universitas Negeri Jakarta

Ateng, Abdul Kadir. 1992. Asas dan Landasan Olahraga. Jakarta. Ditjen Pendidikan Tinggi

bolanews.com/lilianto_apriadi/15447.php -, 9 September 2008

Coackley, Jay. 2001. Sport in Society: Issues \& Controversies. Boston: MacGraw Hill

Dault, Adhyaksa. 2007. Membangkitkan Kembali Peran Pemuda \& Prestasi Olaraga Indonesia yang Terpuruk. Jakarta: Pustaka Indonesia Press

Houlihan, Barrie. 1997. Sport, Policy and Politics: A Comparative Analysis. New York: Routledge

Kartono, Kartini. 1994. Psikologi Sosial. Jakarta: Rineka Cipta

Kompas, 3 Agustus 2009; Detiksport.com, 30 Juni 2009)

Lutan, Rusli. 2000. Sosiologi Olahraga. Jakarta: Direktorat Pendidikan Dasar dan Menengah

Munir, Abdul. 2005. Konflik dan Kekerasan Dalam Masyarakat. Yogyakarta: Aquarius Offset

Ritzer, George. 2005. Encyclopedia of Social Theory, I, II. Tousand Oaks. Sage Publication

www.kapanlagi.com, 21 Agustus 2008 